\title{
Leuconostoc palmae sp. nov., a novel lactic acid bacterium isolated from palm wine
}

\author{
Matthias A. Ehrmann, Simone Freiding and Rudi F. Vogel \\ Lehrstuhl für Technische Mikrobiologie, Technische Universität München, Weihenstephaner Steig \\ 16, 85350 Freising, Germany
}

Correspondence

Matthias A. Ehrmann

M.Ehrmann@wzw.tum.de

\begin{abstract}
A novel lactic acid bacterium, strain TMW $2.694^{\top}$, was isolated among other lactic acid bacteria from palm wine, an alcoholic beverage produced from the sap of various palm tree species. Strain TMW $2.694^{\top}$ is a Gram-positive, facultatively anaerobic, catalase-negative, non-spore-forming coccus, occurring in long chains. Phylogenetic analysis based on 16S rRNA gene sequencing positioned strain TMW $2.694^{\top}$ in a distinct line of descent within the genus Leuconostoc, with the closest neighbours being Leuconostoc lactis JCM $6123^{\top}$ (98.7\% sequence similarity) and Leuconostoc citreum DSM $5577^{\top}$ (98.8\% sequence similarity). Comparative sequencing of the additional phylogenetic markers $d n a K$ and $\operatorname{rec} A$ confirmed the 16S rRNA gene tree topology. Genomic DNA-DNA similarities of strain TMW $2.694^{\top}$ to L. lactis DSM $20202^{\top}$ and L. citreum DSM $5577^{\top}$ were 45.1 and $17.7 \%$, respectively. The DNA G +C content is $36.4 \mathrm{~mol} \%$. Thus, we propose a novel species within the genus Leuconostoc, with the name Leuconostoc palmae sp. nov. and the type strain TMW $2.694^{\top}$ (=DSM $21144^{\top}=$ LMG $24510^{\top}$ ).
\end{abstract}

Palm wine is an alcoholic beverage produced from the sap of various palm tree species. The drink is particularly common in parts of Africa, south India and the Philippines. In Africa, the sap is most often taken from wild date palms such as Phoenix sylvestris (the palmyra) and Caryota urens, from oil palms such as Elaeis guineensis, or from Raphia, kithul or nipa palms (Bassir, 1962). The initial white liquid is rich in sugars and begins to ferment spontaneously after collection, due to natural microorganisms in the plant environment or residual microorganisms left in the collecting container. The sugar composition of the unfermented sap from oil palm trees (e.g. E. guineensis) ranges from 9.59 to $10.59 \%(\mathrm{w} / \mathrm{v})$ sucrose, whereas the concentrations of glucose and fructose are 1.00 and $0.13-0.73 \%(\mathrm{w} / \mathrm{v})$, respectively (Eze \& Ogan, 1988). Raffinose occurs in traces only $(0.13-0.35 \%$, w/v). Within a few hours, fermentation yields an aromatic wine of up to $4 \%$ alcohol content.

Besides fermenting yeasts belonging to various genera, e.g. Saccharomyces, Candida, Endomycopsis, Hansenula, Pichia, Saccharomycodes and Schizosaccharomyces (Faparusi, 1973; Owuama \& Saunders, 1990; Ezeronye \& Okerentugba,

The GenBank/EMBL/DDBJ accession numbers for the $16 \mathrm{~S}$ rRNA, recA and dnaK gene sequences of Leuconostoc palmae TMW $2.694^{\top}$ are AM940225-AM940227, respectively; those for the recA and dnaK gene sequences of Leuconostoc holzapfelii LMG 23990 ${ }^{\top}$ are AM940228 and AM940229, respectively; that for the dnaK gene sequence of Leuconostoc lactis JCM $6123^{\top}$ is AM940230.

Supplementary figures showing maximum-parsimony and maximumlikelihood 16S rRNA gene trees are available with the online version of this paper.
2001), the dominant bacterial population of palm wine was previously described as lactic acid bacteria - strains of Lactobacillus plantarum, Leuconostoc mesenteroides and L. mesenteroides subsp. dextranicum. Acetic acid bacteria occurred only after day 3 of fermentation (Okafor, 1978; Amoa-Awua et al., 2007).

The genus Leuconostoc, which at the time of writing consists of 11 species, encompasses a group of coccoid lactic acid bacteria. Recently, all of the rod-shaped species, i.e. Leuconostoc fructosum, Leuconostoc durionis, Leuconostoc ficulneum and Leuconostoc pseudoficulneum, were reclassified on the basis of phylogenetic and morphological differences into the genus Fructobacillus (Endo \& Okada, 2008). The majority of members of both genera were isolated from sugar-rich substrates, e.g. fruits, vegetables and fermentations thereof and/or meat and dairy products.

In this study, we isolated strain TMW $2.694^{\mathrm{T}}$ from a sample taken from palm wine prepared in Senegal. This strain was conspicuous during routine identification by its $16 \mathrm{~S}$ rRNA gene sequence, which was different from previously published sequences.

Strain TMW $2.694^{\mathrm{T}}$ was cultivated routinely at $30{ }^{\circ} \mathrm{C}$ on glucose-yeast extract-peptone (GYP) medium containing $\left(1^{-1}\right): 10 \mathrm{~g}$ glucose, $3 \mathrm{~g}$ yeast extract, $10 \mathrm{~g}$ peptone, $10 \mathrm{~g}$ meat extract, $5 \mathrm{~g} \mathrm{NaCl}, 2.0 \mathrm{~g}$ sodium acetate, $0.25 \mathrm{~g}$ Tween 80, $200 \mathrm{mg} \mathrm{MgSO}_{4} \cdot 7 \mathrm{H}_{2} \mathrm{O}, 10 \mathrm{mg} \mathrm{MnSO}_{4} \cdot 4 \mathrm{H}_{2} \mathrm{O}, 10 \mathrm{mg}$ $\mathrm{FeSO}_{4} \cdot 7 \mathrm{H}_{2} \mathrm{O}(\mathrm{pH} 6.8)$. Colonies are small $(0.5-1.0 \mathrm{~mm}$ in diameter), circular, smooth, convex and whitish. Cells are Gram-positive, non-motile, non-spore-forming cocci that are $0.5-0.8 \mu \mathrm{m}$ in diameter and occur in extremely long 
chains of up to 40 cells. The coccoid cell shape that distinguishes strain TMW $2.694^{\mathrm{T}}$ from the rod-shaped fructobacilli is shown in Fig. 1. In liquid cultures, cells show a strong tendency toward flocculation and sedimentation.

\section{Physiological characterization}

Strain TMW $2.694^{\mathrm{T}}$ was able to grow at $15-45{ }^{\circ} \mathrm{C}$, but not at temperatures above $45{ }^{\circ} \mathrm{C}$. Optimal growth was observed at $30{ }^{\circ} \mathrm{C}$. The strain tolerated up to $3 \mathrm{~g} \mathrm{NaCl}^{-1}$. It is obligately heterofermentative and $94 \%$ of the total lactic acid produced is of the $\mathrm{D}$ configuration, as determined enzymically by using a D/L-lactate test kit (Roche Diagnostics). As some Leuconostoc species are known to produce high amounts of tyramine (Moreno-Arribas et al., 2003), decarboxylation of amino acids (arginine, aspartate, glutamate, histidine, lysine, ornithine, phenylalanine and tyrosine) was determined by following the procedure described by Bover-Cid \& Holzapfel (1999). No decarboxylation of any amino acid by strain TMW $2.694^{\mathrm{T}}$ was detected.

A sugar-fermentation profile was determined by using API 50 CHL galleries (bioMérieux) with minor modifications. The $\mathrm{pH}$ of the test medium was adjusted to 6.0. All tests were performed in duplicate. Acid is produced from Dglucose, D-fructose, sucrose and D-mannose. Acid is not produced from D-ribose, D-xylose, D-rhamnose, maltose, D-lactose, melibiose or trehalose. Summarized results of morphological, chemotaxonomic and physiological analyses are given in Table 1 and the species description.

\section{Chemotaxonomic characterization}

The DNA G + C content was determined by HPLC analyses at the Deutsche Sammlung von Mikroorganismen und Zellkulturen GmbH (DSMZ; Braunschweig, Germany)

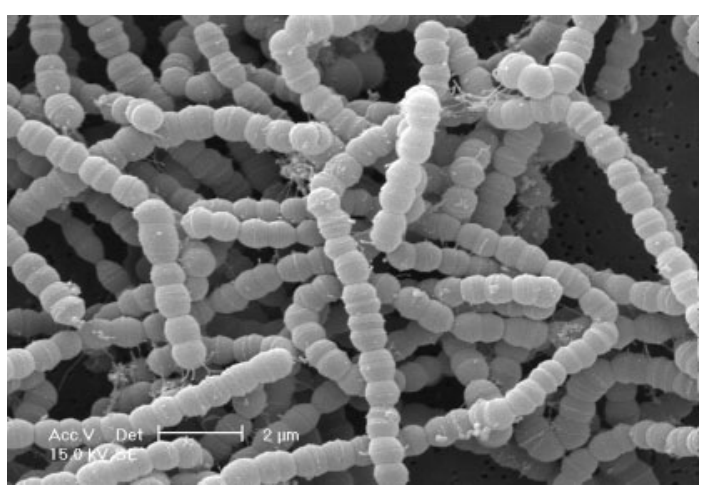

Fig. 1. Electron micrograph of cells of strain TMW $2.694^{\top}$ grown overnight on GYP medium at $30{ }^{\circ} \mathrm{C}$, showing its typical coccoid cell morphology forming long and tangled chains, which distinguishes it from rod-shaped species of the genus Fructobacillus. Bar, $2 \mu \mathrm{m}$.
Table 1. Physiological characteristics of $L$. palmae TMW $2.694^{\top}$ useful in differentiating it from its nearest phylogenetic relatives

Taxa: 1, L. palmae TMW 2.694 ${ }^{\mathrm{T}} ; 2$, L .citreum DSM $5577^{\mathrm{T}}$ (data from Takahashi et al., 1992); 3, L. lactis JCM 6123 ${ }^{\mathrm{T}}$ (Garvie, 1986); 4, L. holzapfelii LMG $23990^{\mathrm{T}}$ (De Bruyne et al., 2007). All taxa produce acid from D-fructose.

\begin{tabular}{|lcccc|}
\hline Characteristic & $\mathbf{1}$ & $\mathbf{2}$ & $\mathbf{3}$ & $\mathbf{4}$ \\
\hline Production of acid & & & & \\
from: & & & & \\
L-Arabinose & - & + & - & + \\
Maltose & - & + & + & + \\
D-Mannose & + & + & - & + \\
Cellobiose & - & + & - & - \\
D-Salicin & - & + & - & - \\
Trehalose & - & + & - & + \\
Melibiose & - & - & - & + \\
Raffinose & - & - & - & + \\
Sucrose & + & + & + & - \\
Gluconate & - & - & - & + \\
DNA G + C content & 36.4 & 43.9 & $43-45$ & 43.5 \\
(mol\%) & & & & \\
\hline
\end{tabular}

following the protocol described by Tamaoka \& Komagata (1984) and according to Mesbah et al. (1989). The DNA G+C content of strain TMW $2.694^{\mathrm{T}}$ is $36.4 \mathrm{~mol} \%$, which is within the range reported for Leuconostoc species (Garvie, 1986). The peptidoglycan structure of the cell wall was determined at the DSMZ. Analysis of the cell-wall composition of strain TMW $2.694^{\mathrm{T}}$ revealed the presence of alanine, glutamic acid and lysine $(4.2: 1.0: 0.8)$ after total hydrolysis $(4 \mathrm{M} \mathrm{NaOH}, 16 \mathrm{~h}$, $\left.100{ }^{\circ} \mathrm{C}\right)$. Peptides obtained by partial hydrolysis $(4 \mathrm{M}$ $\left.\mathrm{NaOH}, 0.75 \mathrm{~h}, 100{ }^{\circ} \mathrm{C}\right)$ indicate peptidoglycan type $\mathrm{A} 3 \alpha(\mathrm{L}-$ Lys-L-Ala ), corresponding to type A11.5 (http:// www.dsmz.de/microorganisms/main.php?content_id=35).

\section{Phylogenetic analyses}

To determine the phylogenetic position of strain TMW $2.694^{\mathrm{T}}$, the 16S rRNA gene was sequenced over a continuous stretch of $1531 \mathrm{bp}$. DNA was isolated with an E.Z.N.A. Bacterial DNA kit (Omega Bio-Tek) according to the manufacturer's instructions.

PCR products amplified with primers $616 \mathrm{~V}$ ( $5^{\prime}$-AGAGTTTGATYMTGGCTCAG-3') and 6130R (5'-CAKAAAGGAGGTGATCC-3') were purified by a QIAquick PCR Purification kit (Qiagen) and eluted with $60 \mu \mathrm{l}$ elution buffer. DNA sequences were determined by the chaintermination method using an ABI Prism Dye Terminator Cycle Sequencing kit (Applied Biosystems). The 16S rRNA gene sequence of strain TMW $2.694^{\mathrm{T}}$ was compared with those of the most closely related species retrieved from GenBank. A phylogenetic tree on the basis of a multiple alignment-based similarity matrix was constructed by the 


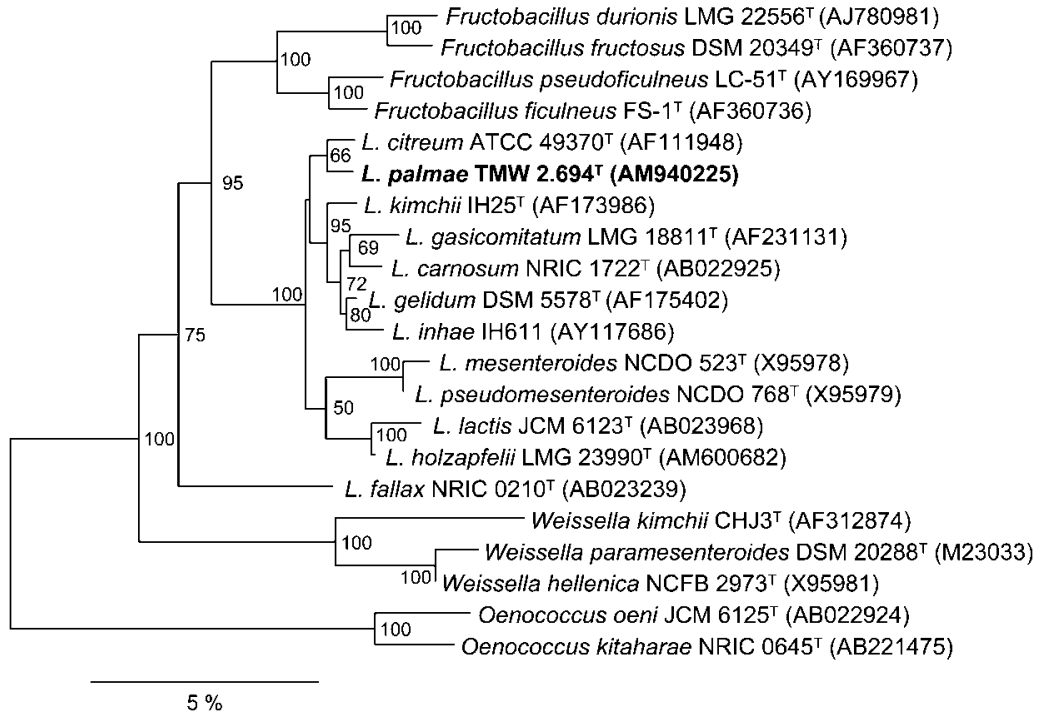

Fig. 2. Neighbour-joining tree derived from $16 \mathrm{~S}$ rRNA gene sequence analysis, showing the relationship of $L$. palmae TMW $2.694^{\top}$ to members of the genus Leuconostoc. The Oenococcus clade was used as an outgroup. Approximately $1500 \mathrm{nt}$ from each sequence was used for the alignment. Bar, $5 \%$ estimated sequence divergence. Numbers indicate bootstrap values $>50 \%$ (percentage of 100 replications). neighbour-joining method (Saitou \& Nei, 1987) by using the software package Bionumerics, version 3.50 (Applied Maths). Unknown bases were discarded for the analyses. Bootstrapping analysis was undertaken to test the statistical reliability of the topology of the neighbour-joining tree, using 100 bootstrap resamplings of the data (Fig. 2). This analysis positioned strain TMW $2.694^{\mathrm{T}}$ in a distinct line of descent within the genus Leuconostoc, with the closest
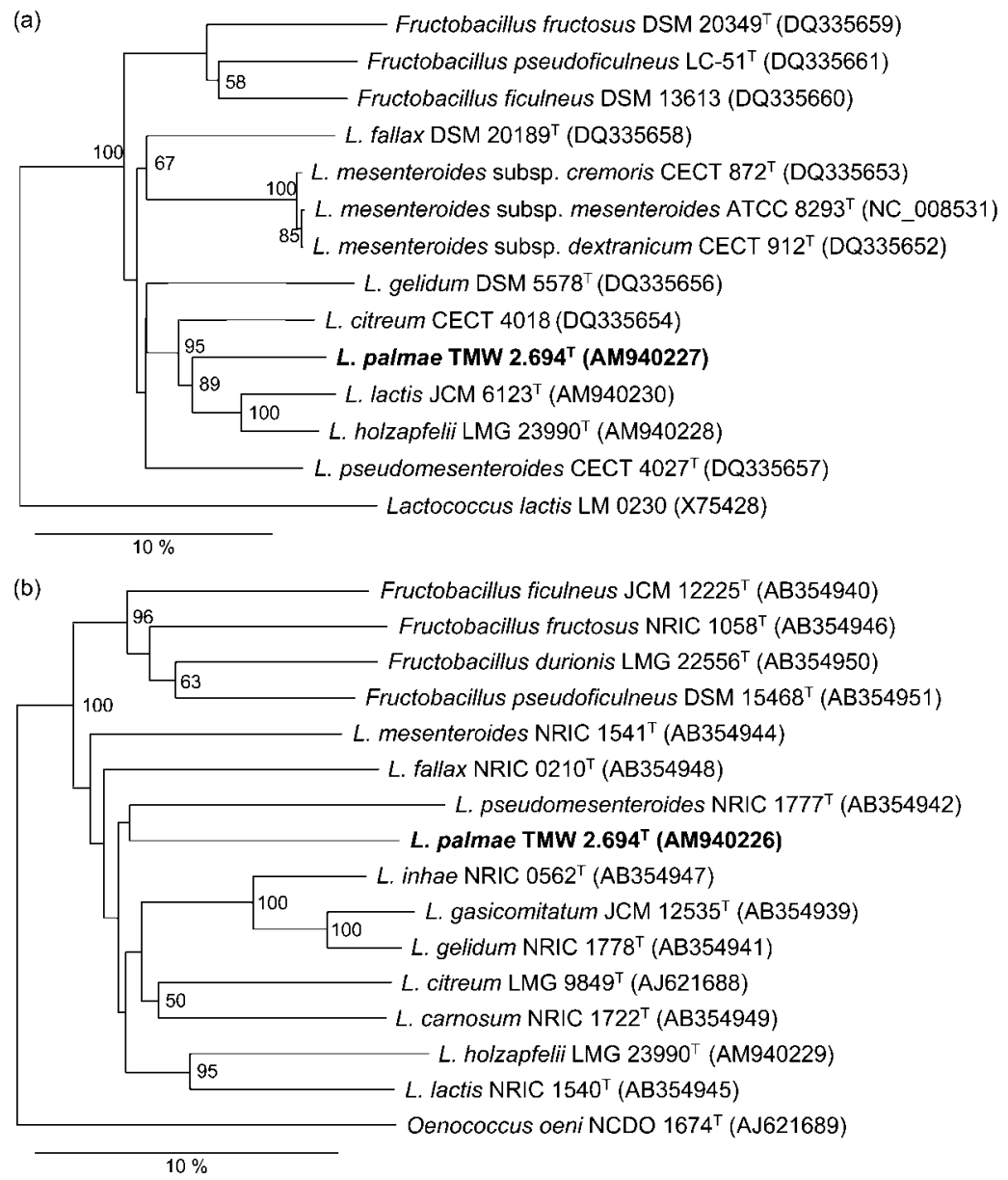

Fig. 3. Neighbour-joining trees obtained with partial protein-encoding sequences of the (a) dnaK (735 nt) and (b) recA (1810 nt) genes, showing the relationship of $L$. palmae TMW $2.694^{\top}$ to members of the genera Leuconostoc and Fructobacillus. The sequences of Lactococcus lactis (dnaK) and Oenococcus oeni $(\operatorname{rec} A)$ were used as outgroup representatives. Bars, $10 \%$ estimated sequence divergence. Numbers indicate bootstrap values $>50 \%$ (percentage of 100 replications). 
neighbours being Leuconostoc lactis JCM $6123^{\mathrm{T}}(98.7 \%$ similarity) and Leuconostoc citreum DSM $5577^{\mathrm{T}}(98.8 \%$ similarity). Alternative treeing methods (maximum parsimony and maximum likelihood) result in an essentially similar phylogenetic position (see Supplementary Figs S1 and S2, available in IJSEM Online).

A higher resolution than that provided by $16 \mathrm{~S}$ rRNA gene sequence data at the species level is achievable by the simultaneous comparison of additional molecular markers throughout the bacterial chromosome. Multilocus sequencing of protein-encoding genes has become a common approach, especially in the resolution of close taxa (Konstantinidis \& Tiedje, 2005). Therefore, comparative sequence analyses of the $r e c A$ and $d n a K$ genes were performed. Sequences for strain TMW $2.694^{\mathrm{T}}$ and those of reference strains whose rec $A$ and $d n a K$ sequences were not available in public databases (Leuconostoc holzapfelii and $L$. lactis) were amplified by using primers and PCR conditions as described by Dellaglio et al. (2005) and Chelo et al. (2007), respectively. Analysed sequence lengths were 1815 and $710 \mathrm{bp}$ for $d n a K$ and $r e c A$, respectively. Tree construction for phylogenetic analyses was performed as descibed above. The recA and dnaK trees revealed only moderate consistency with the 16S rRNA gene-derived topology, showing marked differences in the branching order (Fig. 3). Whilst in the $d n a K$ tree, strain TMW $2.694^{\mathrm{T}}$ clusters closely with $L$. lactis, $L$. holzapfelii and $L$. citreum in one coherent group, it clusters in the recA tree with Leuconostoc pseudomesenteroides, albeit rather distantly. Discrepancies may be explained by the different dataset (not all sequences of all species were available), different sequence lengths of genes, weak bootstrap support (especially within the recA tree) or differences in the apparent rate of evolution of protein-encoding genes with respect to the 16S rRNA gene in this and related genera (Chelo et al., 2007). Nevertheless, each of these trees corroborates the separate species status of strain TMW $2.694^{\mathrm{T}}$.

To evaluate and establish a fast screening method, random amplification of polymorphic DNA (RAPD) analysis was carried out with DNA of strain TMW $2.694^{\mathrm{T}}$ and 10 type strains of additional Leuconostoc species. All strains tested showed clearly different profiles (Fig. 4) with primer M13V (5'-GTTTTCCCAGTCACGAC-3') under conditions described previously (Ehrmann et al., 2003) with minor modifications. The cycling program was three cycles of $94{ }^{\circ} \mathrm{C}$ for $3 \mathrm{~min}, 40{ }^{\circ} \mathrm{C}$ for $5 \mathrm{~min}$ and $72{ }^{\circ} \mathrm{C}$ for $5 \mathrm{~min}$; 32 cycles of $94{ }^{\circ} \mathrm{C}$ for $1 \mathrm{~min}, 6{ }^{\circ} \mathrm{C}$ for $2 \mathrm{~min}, 72{ }^{\circ} \mathrm{C}$ for $3 \mathrm{~min}$. Taq polymerase was obtained from MP Biomedical. The polymerase buffer contained $5 \mathrm{mM} \mathrm{MgCl}_{2}$.

\section{DNA-DNA hybridization}

DNA-DNA similarity values were determined by using chromosomal DNA of strain TMW $2.694^{\mathrm{T}}$ and its closest phylogenetic neighbours in the 16S rRNA gene tree, $L$. citreum and L. lactis. Renaturation kinetics were performed at the DSMZ after the protocol of De Ley et al. (1970) with

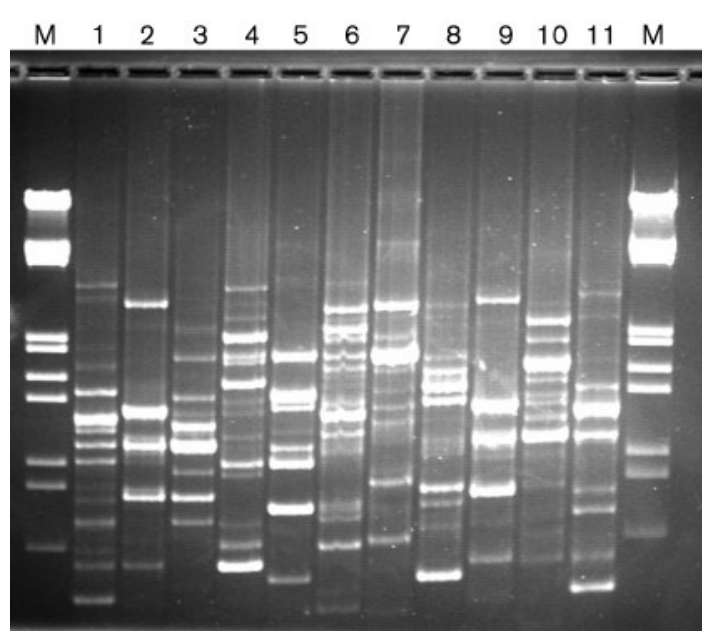

Fig. 4. RAPD profiles differentiating L. palmae TMW $2 \cdot 694^{\top}$ from other Leuconostoc species. Lanes: 1, L. pseudomesenteroides TMW 1.201 (isolated from palm wine); 2, L. citreum TMW 2.695 (palm wine); 3; L. palmae TMW 2.694 ${ }^{\top}$ (DSM 21144 ${ }^{\top}$, palm wine); 4, L. holzapfelii LMG $23990^{\top} ; 5$, L. carnosum DSM 5576 ${ }^{\top} ; 6$, L. lactis DSM $20202^{\top} ; 7$, L. fallax DSM $20189^{\top} ; 8$, L. gelidum DSM $5578^{\top}$; 9, L. citreum DSM 5577 ${ }^{\top}$; 10, L. mesenteroides subsp. dextranicum DSM 20484 ${ }^{\top} ; 11$, L. pseudomesenteroides DSM $20193^{\top}$; M, DNA marker.

modifications described by Huß et al. (1983) and Escara \& Hutton (1980). All experiments were performed in duplicate. The values of the DNA-DNA reassociation of TMW $2.694^{\mathrm{T}}$ to L. lactis DSM $20202^{\mathrm{T}}$ and L. citreum DSM $5577^{\mathrm{T}}$ were 45.1 and $17.7 \%$, respectively. These values are far below the $70 \%$ border recommended as the boundary value for isolates allocated to the same species (Wayne et al., 1987; Stackebrandt \& Goebel, 1994; Rosselló-Mora \& Amann, 2001).

Taken together, the presented phenotypic and genotypic data confirm that strain TMW $2.694^{\mathrm{T}}$ represents a novel species in the genus Leuconostoc, for which we propose the name Leuconostoc palmae sp. nov.

\section{Description of Leuconostoc palmae sp. nov.}

Leuconostoc palmae (pal'mae. L. gen. n. palmae of a palm tree).

On GYP agar, colonies are small $(0.5-1.0 \mathrm{~mm}$ in diameter), circular, smooth, convex and whitish. Cells are Grampositive, non-motile, non-spore-forming cocci that are $0.5-$ $0.8 \mu \mathrm{m}$ in diameter and occur in very long chains of up to 40 cells. In liquid culture, cells show a strong tendency toward flocculation and sedimentation. Weak growth is observed at $15{ }^{\circ} \mathrm{C}$ and almost no growth occurs at $45{ }^{\circ} \mathrm{C}$ after $48 \mathrm{~h}$. Optimal growth occurs at $30^{\circ} \mathrm{C}$. Facultatively anaerobic; produces almost exclusively D-lactic acid (94\%). Cells are catalase-negative and gas is produced from glucose. Growth occurs at up to $3 \% \mathrm{NaCl}$. No growth is observed at $5 \%$ 
$\mathrm{NaCl}$ or higher. Acid is produced from D-glucose, Dfructose, sucrose and D-mannose. Acid is not produced from D-ribose, D-xylose, D-rhamnose, maltose, D-lactose, melibiose or trehalose. The DNA G $+\mathrm{C}$ content is $36.4 \mathrm{~mol} \%$. Arginine is not hydrolysed. Tyrosine is not decarboxylated. The peptidoglycan type is $\mathrm{A} 3 \alpha$ ( $\mathrm{L}-\mathrm{Lys}-\mathrm{L}-\mathrm{Ala}_{2}$ ).

The type strain, TMW $2.694^{\mathrm{T}}\left(=\mathrm{DSM} 21144^{\mathrm{T}}=\mathrm{LMG}\right.$ $24510^{\mathrm{T}}$ ), was isolated from palm wine prepared in Senegal.

\section{Acknowledgements}

We are grateful to Horst Neve (Max Rubner-Institut, Kiel, Germany) for preparing the electron micrograph and to Monika Hadek for technical assistance.

\section{References}

Amoa-Awua, W. K., Sampson, E. \& Tano-Debrah, K. (2007). Growth of yeasts, lactic and acetic acid bacteria in palmwine during tapping and fermentation from felled oil palm (Elaeis guineensis) in Ghana. J Appl Microbiol 102, 599-606.

Bassir, O. (1962). Observations on the fermentation of palm wine. West Afr J Biol Appl Chem 6, 20-25.

Bover-Cid, S. \& Holzapfel, W. H. (1999). Improved screening procedure for biogenic amine production by lactic acid bacteria. Int $J$ Food Microbiol 53, 33-41.

Chelo, I. M., Zé-Zé, L. \& Tenreiro, R. (2007). Congruence of evolutionary relationships inside the Leuconostoc-OenococcusWeissella clade assessed by $16 \mathrm{~S}$ rRNA gene, dnaA, gyrB, rpoC and dnaK phylogenetic analysis. Int J Syst Evol Microbiol 57, 276-286.

De Bruyne, K., Schillinger, U., Caroline, L., Boehringer, B., Cleenwerck, I., Vancanneyt, M., De Vuyst, L., Franz, C. M. A. P. \& Vandamme, P. (2007). Leuconostoc holzapfelii sp. nov., isolated from Ethiopian coffee fermentation and assessment of sequence analysis of housekeeping genes for delineation of Leuconostoc species. Int J Syst Evol Microbiol 57, 2952-2959.

De Ley, J., Cattoir, H. \& Reynaerts, A. (1970). The quantitative measurement of DNA hybridization from renaturation rates. Eur $J$ Biochem 12, 133-142.

Dellaglio, F., Felis, G. E., Castioni, A., Torriani, S. \& Germond, J.-E. (2005). Lactobacillus delbrueckii subsp. indicus subsp. nov., isolated from Indian dairy products. Int J Syst Evol Microbiol 55, 401-404.

Ehrmann, M. A., Müller, M. R. \& Vogel, R. F. (2003). Molecular analysis of sourdough reveals Lactobacillus mindensis sp. nov. Int J Syst Evol Microbiol 53, 7-13.

Endo, A. \& Okada, S. (2008). Reclassification of the genus Leuconostoc, and proposals of Fructobacillus fructosus gen. nov., comb. nov., Fructobacillus durionis comb. nov., Fructobacillus ficulneus comb. nov. and Fructobacillus pseudoficulneus comb. nov. Int J Syst Evol Microbiol 58, 2195-2205.
Escara, J. F. \& Hutton, J. R. (1980). Thermal stability and renaturation of DNA in dimethyl sulfoxide solutions: acceleration of renaturation rate. Biopolymers 19, 1315-1327.

Eze, M. O. \& Ogan, U. (1988). Sugars of the unfermented sap and the wine from the oil palm, Elaeis guinensis, tree. Plant Foods Hum Nutr 38, 121-126.

Ezeronye, O. U. \& Okerentugba, P. O. (2001). Genetic and physiological variants of yeast selected from palm wine. Mycopathologia 152, 85-89.

Faparusi, S. L. (1973). Origin of initial microflora of palm wine from oil palm trees (Elaeis guineensis). J Appl Microbiol 36, 559-565.

Garvie, E. I. (1986). Genus Leuconostoc van Tieghem 1878. In Bergey's Manual of Systematic Bacteriology, vol. 2, pp. 1071-1075. Edited by P. H. A. Sneath, N. S. Mair, M. E. Sharpe \& J. G. Holt. Baltimore: Williams \& Wilkins.

Huß, V. A. R., Festl, H. \& Schleifer, K. H. (1983). Studies on the spectrophotometric determination of DNA hybridization from renaturation rates. Syst Appl Microbiol 4, 184-192.

Konstantinidis, K. T. \& Tiedje, J. M. (2005). Towards a genome-based taxonomy for prokaryotes. J Bacteriol 187, 6258-6264.

Mesbah, M., Premachandran, U. \& Whitman, W. B. (1989). Precise measurement of the $\mathrm{G}+\mathrm{C}$ content of deoxyribonucleic acid by highperformance liquid chromatography. Int J Syst Bacteriol 39, 159-167.

Moreno-Arribas, M. V., Polo, M. C., Jorganes, F. \& Muñoz, R. (2003). Screening of biogenic amine production by lactic acid bacteria isolated from grape must and wine. Int J Food Microbiol 84, 117-123.

Okafor, N. (1978). Microbiology and biochemistry of oil-palm wine. In Advances in Applied Microbiology (vol. 24), pp. 237-256. Edited by D. Perlman. New York: Academic Press.

Owuama, C. I. \& Saunders, J. R. (1990). Physiological variants of Saccharomyces cerevisiae and Kloeckera apiculata from palm wine and cashew juice. J Appl Bacteriol 68, 491-494.

Rosselló-Mora, R. \& Amann, R. (2001). The species concept for prokaryotes. FEMS Microbiol Rev 25, 39-67.

Saitou, N. \& Nei, M. (1987). The neighbor-joining method: a new method for reconstructing phylogenetic trees. Mol Biol Evol 4, 406-425.

Stackebrandt, E. \& Goebel, B. M. (1994). Taxonomic note: a place for DNA-DNA reassociation and $16 \mathrm{~S}$ rRNA sequence analysis in the present species definition in bacteriology. Int J Syst Bacteriol 44, 846849.

Takahashi, M., Okada, S., Uchimura, T. \& Kozaki, M. (1992). Leuconostoc amelibiosum Schillinger, Holzapfel, and Kandler 1989 is a later subjective synonym of Leuconostoc citreum Farrow, Facklam, and Collins 1989. Int J Syst Bacteriol 42, 649-651.

Tamaoka, J. \& Komagata, K. (1984). Determination of DNA base composition by reversed-phase high-performance liquid chromatography. FEMS Microbiol Lett 25, 125-128.

Wayne, L. G., Brenner, D. J., Colwell, R. R., Grimont, P. A. D., Kandler, O., Krichevsky, M. I., Moore, L. H., Moore, W. E. C., Murray, R. G. E. \& other authors (1987). International Committee on Systematic Bacteriology. Report of the ad hoc committee on reconciliation of approaches to bacterial systematics. Int J Syst Bacteriol 37, 463-464. 